Article

\title{
Topographic Anaglyphs from Detailed Digital Elevation Models Covering Inland and Seafloor for the Tectonic Geomorphology Studies in and around Yoron Island, Ryukyu Arc, Japan
}

\author{
Hideaki Goto ${ }^{1, *}$, Kohsaku Arai ${ }^{2}$ and Taichi Sato ${ }^{2}$ \\ 1 Department of Geography, Hiroshima University, Higashihiroshima 739-8522, Japan \\ 2 The National Institute of Advanced Industrial Science and Technology (AIST), Tsukuba, \\ Ibaraki 305-8560, Japan; ko-arai@aist.go.jp (K.A.); taichi-sato@aist.go.jp (T.S.) \\ * Correspondence: hgoto@hiroshima-u.ac.jp; Tel.: +81-82-424-6658
}

Received: 3 August 2018; Accepted: 25 September 2018; Published: 29 September 2018

\begin{abstract}
Anaglyphs produced using a digital elevation model (DEM) are effective to identify the characteristic tectono-geomorphic features. The objective of this study is to reinvestigate the tectonic geomorphology and to present novel tectonic maps of the late Quaternary in and around the Yoron island based on the interpretation of extensive topographical anaglyphs along the map areas that cover the inland and seafloor. Vintage aerial photographs are used to produce the 3-m mesh inland digital surface model (DSM); further, the 0.6-s to 2-s-mesh seafloor DEM is processed using the cloud point data generated through previous surveys. Thus, we identify anticlinal deformation on both the Pleistocene marine terrace and the seafloor to the north of the island. The deformation axis extends in a line and is parallel to the general trend of the island shelf. The Tsujimiya fault cuts the marine terraces, which extend to the Yoron basin's seafloor. If we assume that the horizontal compressive stress axis is perpendicular to the island shelf, these properties can easily explain the distribution and style of the active faults and deformation. This study presents an effective methodology to understand the island arc tectonics, especially in case of small isolated islands.
\end{abstract}

Keywords: topographical anaglyph; tectonic geomorphology; emerged coral reef; Yoron island; DEM

\section{Introduction}

When the topographic anaglyph images are viewed using red-cyan glasses, the topographic relief features can be easily identified [1]. Anaglyphs produced using the digital elevation model (DEM) data are effective to identify the tectonic geomorphic features such as small fault scarps, broad ground deformation, and tilting surfaces [2-4]. The analysis and interpretation of topographic anaglyphs along the eastern margin of the Japan Sea and the Japan trench reveal the distribution of active deep submarine faults $[5,6]$. Nakata et al. (2012) discussed the relation between the tectonic seafloor features and earthquake source faults during the 2011 Tohoku Pacific Ocean earthquake and concluded that active submarine faults were closely related to the earthquake source faults [5].

In coastal areas, detailed seafloor bathymetric data acquired using narrow multibeam sonar system have revealed unique topographic features such as fault scarps [7], submerged karst landforms [8], submarine landslides [9], and submerged marine terraces [10,11]. However, these studies have primarily focused on seafloor topography; furthermore, the studies that examine the deformation that appears both on the inland surface and the seafloor are sparse. Tectonic deformation along the coastal marine depths often extends inland so that we can use the detailed topographic data, 
which encompasses both the inland and seafloor areas, to understand the direction, distance, and style of deformation that occurs or may occur.

This study intends to reinvestigate the tectonic geomorphology and create new tectonic maps, for the late Quaternary in and around the Yoron islands, based on the analysis and interpretation of topographic anaglyphs derived from 3-m mesh digital surface models (DSM) of inland regions, as well as the 0.6-s to 2-s-mesh seafloor DEMs. Vintage aerial photographs were used to produce the inland DSMs, and seafloor DEMs were created using the cloud point data from multibeam echo-sounding devices provided by the National Institute of Advanced Industrial Science and Technology (AIST) as well as the Japan Agency for Marine-Earth Science and Technology (JAMSTEC).

Using the topographic anaglyph interpretation, we observe that NNW-trending left lateral strike-slip faults at the Yoron island, extend across the island arc to the north into the Yoron basin. Anticlinal deformation was also observed along the marine terraces in northeastern regions of Yoron island, as well as on the seafloor to the north of Yoron island along the island shelf. This deformation runs parallel to the eastern margin of the Yoron basin, as well as the Nanseishoto (Ryukyu) trench. The objective of this study is to apply the improved methods to further understand the island arc tectonics because, globally, active faults and the tectonic deformation have been observed in only a small portion of an island arc that comprises isolated islands.

\section{Tectonic Setting}

Yoron island is located in the central part of the Nanseishoto islands, which extend in a NE trending direction along the island shelf whose topography is essentially formed by the subduction of the Philippine Sea plate beneath the Eurasian plate along the Nanseishoto trench (Figure 1A). The Okinawa trough is developed via the back-arc extension of the Ryukyu arc, which is parallel to the Nanseishoto islands and the Nanseishoto trench. The EW to ENE trending grabens, which are associated with normal faulting, occur in the southwestern region of the trough, which is aligned along the trough throughout the middle to the northern regions, and at which several active volcanos exist [12].

In the mid Nanseishoto islands, three islands (Tokunoshima, Okinoerabu-jima, and Yoron islands), spaced at an interval of 20-40 km, occur in a line between the Amami-Oshima and Okinawa islands (Figure 1B). The coastal areas of these islands exhibit numerous well-developed coral reefs along the uplifted marine terraces [13], which indicates that the uplift occurred during the mid to late Quaternary. According to the results of a seismic profiling survey [14], the Plio-Pleistocene sediments beneath the uplifted coral reefs were tilted to the trench. This survey also detected Miocene sediments with thicknesses of greater than $500 \mathrm{~m}$ beneath the Yoron basin. Arai et al. (2015) suggested that the Yoron basin should be developed as a half graben, which led to the hypothesis that cliffs that were taller than $500 \mathrm{~m}$ on the eastern side of the Yoron basin were fault scarps. 


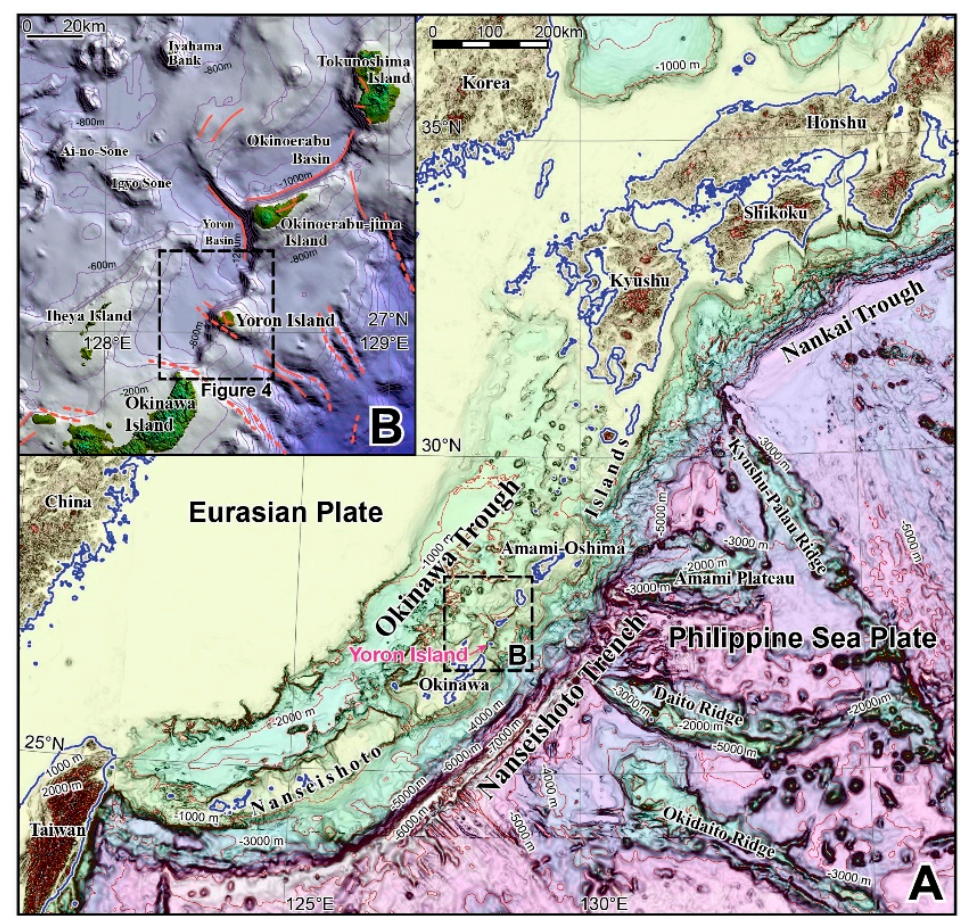

Figure 1. Topography along the Nanseishoto (Ryukyu) trench (A) and around the study area (B). Shaded relief maps overlain by contour maps use a 500-m mesh DEM (J-EGG500) from the Japanese Coast Gard (JCG), a 1-degree-mesh DEM (ETOPO 1) provided by the National Center for Environmental Information (U.S.A), and on-land SRTM-3 data provided by the USGS. Red lines in (B) are indicated the active fault lines after [15].

Previous studies have reported the occurrence of several small active fault strands that have cut and deformed the marine terraces that occur along the Tokunoshima, Okinoerabu-jima, and Yoron islands [15]. However, the extension and style of faulting are not well documented because certain areas of the island and terraces have limited exposure, and there is a lack of detailed topographic data.

Yoron island was formed via the uplifted coral reefs, and marine terraces covered the surfaces of the island $[15,16]$. The present-day coral reefs are well developed in and around the Yoron island, especially along the eastern shore. Fault scarps that trend NNW, cut these surfaces and extend across the central portion of the island. The present-day coral reefs also contain these fault scarps [15].

\section{Data and Methods}

The 10-m mesh digital elevation model (DEM), published by the Geospatial Information Authority of Japan (GSI), is the highest resolution data that is publicly available for the Yoron island. This DEM was created from contours with an interval of $10 \mathrm{~m}$ on a 1:25,000 scaled topographical map, such that small topographies, e.g., old crests along the uplifted coral reefs, are not visible. The ALOS Global Digital Surface Model (AW3D30) DEM, with a horizontal pixel size of approximately $~ 30-\mathrm{m}$ mesh released by the Japan Aerospace Exploration Agency in 2016, is useful in tectonic geomorphology [17] and available for Yoron island. The construction of square, large cultivated fields that were originally small rounded fields affected by karst sinkholes, partially destroyed the small topography throughout the Yoron island, while topography before destruction is visible on the aerial photographs that were taken in the 1970s, which were the oldest existing large-scale color photographs.

The software adopted SfM (structure from motion) -MVS (multi-view stereo) technology, such as Agisoft PhotoScan ${ }^{\circledR}$, enables the creation of topographical models using aerial photographs and recorded geographical coordinates, i.e., ground control points (GCPs) $[18,19]$. We adapted the vintage colored GSI (COK-77-1) photographs, which were taken in 1977, at a scale of approximately 1:10,000 (Table 1), and longitude and latitude information from the unalterable points on the ground acquired 
using GNSS (Spectra Precision Promark 120) in the field to ensure processing using PhotoScan Professional Edition ${ }^{\circledR}$ version 1.2.6. Therefore, we generated a 0.12-s-mesh (approximately $3 \mathrm{~m}$ ) inland DSM.

The National Institute of Advanced Industrial Science and Technology (AIST), conducted a multibeam survey from the north of Okinawa to the Okinoerabu-jima island in 2012 [20]. The JAMSTEC (2016) stored and disseminated information for the rock and sediment core samples, as well as the results of the multibeam survey on their website, "Data and Sample Research System for Whole Cruise Information in JAMSTEC" [21]. We collected these data using the AIST and JAMSTEC, to generate the 0.6-s-mesh (approximately $19 \mathrm{~m}$ ) and the 2-s-mesh (approximately $65 \mathrm{~m}$ ) seafloor DEMs, respectively. We reprocessed the 2-s-mesh DEM using digital bathymetric charts (M7020) with 1-2 m interval counters, proposed by the Japan Hydrographic Association (JHA), following the methods of [22]. We combined these DEMs with the 500-m-mesh DEM (J-EGG500) published by the Japan Coast Gard (JCG). These were overlapped in according to the decreasing resolution.

We imported both the inland and seafloor DSMs into Simple DEM Viewer ${ }^{\circledR}$. We further produced an anaglyph image that was overlapped onto the black and white slope shading map and the black and white shaded relief base map, for stereoscopic analysis with red-cyan glasses.

\section{Results}

\subsection{Inland DSM Accuracy Assessment}

We produced the DSM based on aerial photographs from 1977, with a resolution of $0.204 \mathrm{~m}$ (Table 1). The GCP residual error was approximately $1.8 \mathrm{~m}$ (Figure 2, Table 2). Validation using 8 points, revealed that this DSM exhibits a height of a root mean squared error (RMSE) of $2.6 \mathrm{~m}$. We observed no inclination or distortion in the model itself. This DSM is sufficiently accurate to measure the fault scarp height, as well as the crest of the marine terrace. However, this DSM has too fine a resolution to recognize and analyze the geomorphic features on the Yoron island region, with an area of $20.8 \mathrm{~km}^{2}$. Thus, we converted the 0.814-m mesh DSM to a 0.12-s-mesh (approximately $3 \mathrm{~m}$ ) DSM. The 0.12-s-mesh DSM exhibits a sufficient resolution, allowing the detection of microtopography such as sugar cane fields affected by karst sinkholes, and the crests of marine terraces.

Table 1. Aerial photograph properties used in this study.

\begin{tabular}{lcccccccc}
\hline Date D/M/Y & Camera Type & $\begin{array}{c}\text { Focal Length } \\
(\mathbf{m m})\end{array}$ & $\begin{array}{c}\text { Aerial Platform } \\
\text { Altitude }(\mathbf{m})\end{array}$ & Scale * & $\begin{array}{c}\text { Number of } \\
\text { Flights }\end{array}$ & $\begin{array}{c}\text { Number of } \\
\text { Image }\end{array}$ & $\begin{array}{c}\text { Scan Pitch } \\
(\mathbf{m m})\end{array}$ & $\begin{array}{c}\text { Resolution on } \\
\text { Ground }(\mathbf{c m})\end{array}$ \\
\hline $11 / 24 / 1977$ & RC-10 (Color) & 153.09 & 1600 & 10,451 & 4 & 33 & 0.02 & 20.4 \\
\hline
\end{tabular}

* Calculated value from focal length and altitude.

Table 2. The RMSE control points.

\begin{tabular}{ccccccc}
\hline Count & X Error $(\mathrm{m})$ & Y Error $(\mathrm{m})$ & Z Error $(\mathbf{m})$ & XY Error $(\mathrm{m})$ & Total $(\mathbf{m})$ & Image $($ Pixel) \\
\hline 21 & 1.40983 & 1.15753 & 1.9152 & 1.82414 & 2.6449 & 2.105 \\
\hline
\end{tabular}




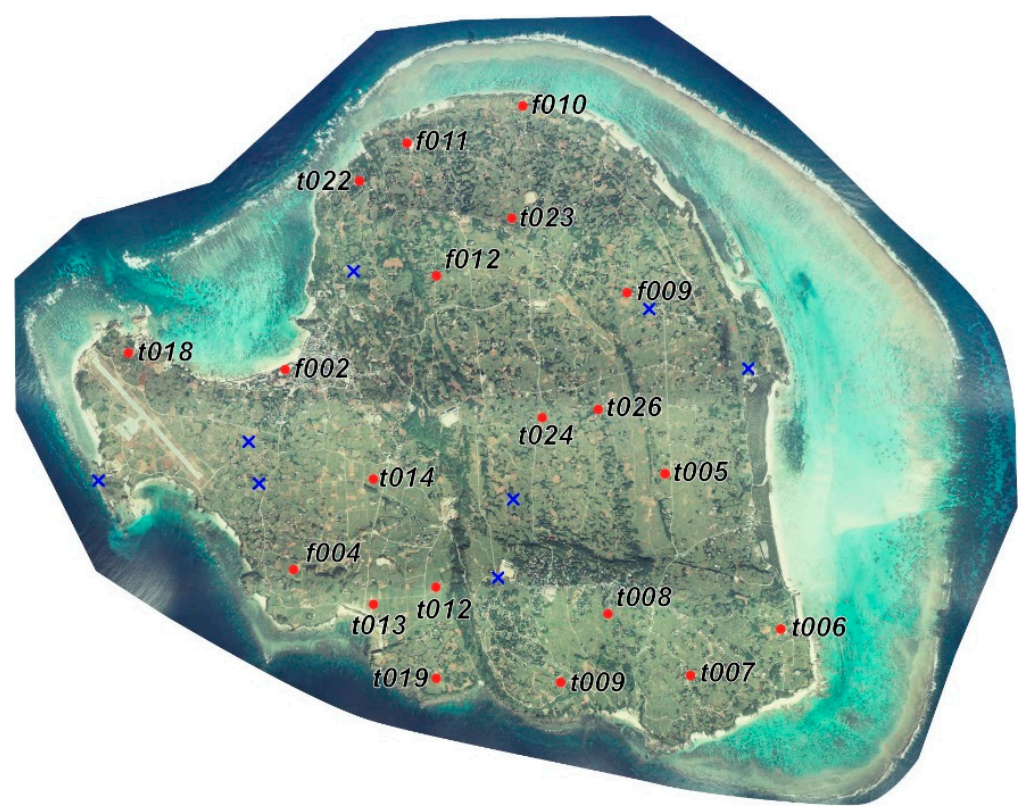

Figure 2. Orthophoto of the Yoron island exhibiting the Ground Control Points (GCP) location (red circle marks) and the assessment point altitudes (blue $\mathrm{X}$ marks).

\subsection{Active Fault Scarps and Ground Deformation Deduced from Topographic Anaglyphs}

We identified active fault scarps and surface deformation on both the inland and seafloor, via anaglyph interpretation using red-cyan glasses. Identification criteria for this study are identical to those used by previous studies [15].

\subsubsection{Active Fault Scarps on the Yoron Island}

On the Yoron island, previous studies have analyzed the Tsujimiya fault, which trends NNW across the island, and the Asato fault, which trends to the southeast $[15,23]$. Based on the terrace riser offset of the lowest marine terrace, previous studies suggested that the Tsujimiya fault is a left-lateral strike-slip fault [15].

We identified the scarps of these faults on the topographic anaglyph (Figure 3A). The Tsujimiya fault scarp in the southern region, is isolated and faces west, with a height of less than $80 \mathrm{~m}$ (Figure 3B). We observe several scarps in the mid and northern regions, which branch to the north from the island's center, and have heights of several to 20 meters each. Surfaces near the top of the cliff in the southern region, tilt to the southeast (Figure 3B). These fault scarps merge with the coast line on both sides of the scarp. Based on the distribution of visible reefs during low tide, we observe that the Tusjimiya fault intersects with the coral reefs throughout the northern region [15].

We identified several circular arc-shaped cliffs along the Tsujimiya fault scarps; however, these scarps appear slightly unclear in the central region of the Yoron island, where the Tsujimiya fault merges with the Asato fault. Landslide movement has been suggested to have destroyed several of the Tsujimiya fault scarps, possibly due to faulting related to the Asato fault. 

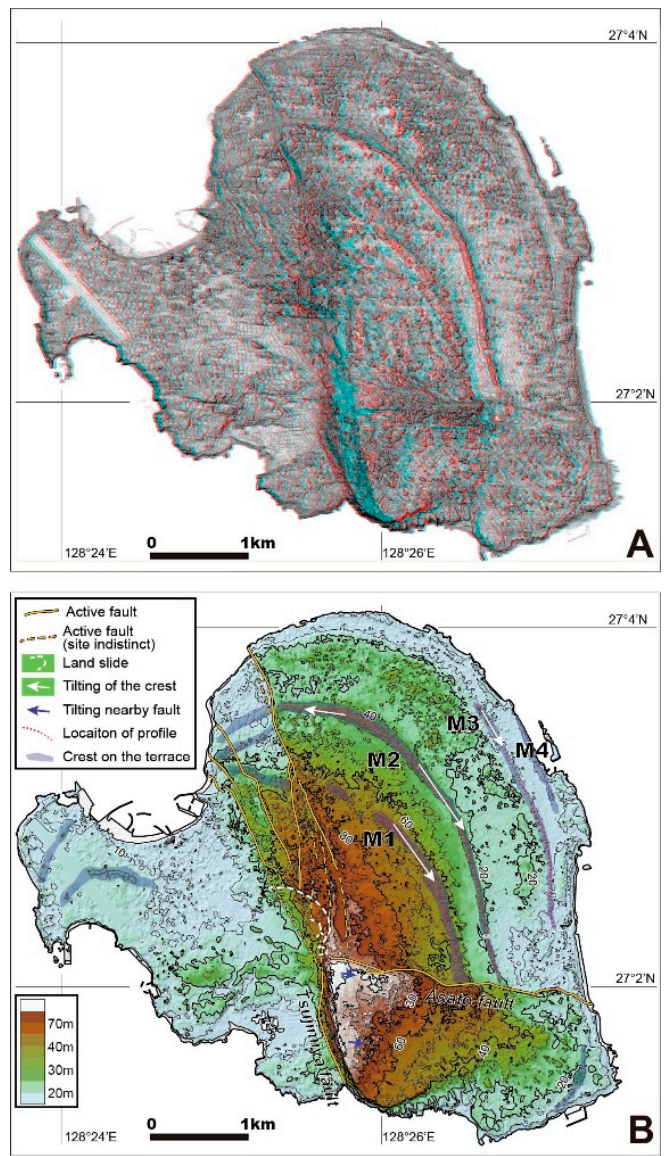

Figure 3. (A) Topographical anaglyph of the Yoron island; (B) Topographical map of the Yoron island, overlain by the active fault distribution and uplifted coral reef crests. Both $(\mathbf{A}, \mathbf{B})$ are based on the DSM processed using vintage photographs in this study. The labels of "M1", “M2", "M3", "M4" in (B) are indicated the name of the marine terraces.

\subsubsection{Active Submarine Faults in the Yoron Basin}

We identified several small scarps that trend NNW and face the southwest along the seafloor in the Yoron basin, associated with the Tsujimiya fault extension on the topographical anaglyph (Figure 4A). These small scarps, with a height of 5-25 m, extend along the flat depositional surfaces throughout the Yoron basin (Figure 4B). Thus, we suggest that these scarps are formed via recent faulting events. These results agree with the results from recent seismic profiling surveys [24]. Fault traces contain several stepping faults with lengths of several kilometers. Its location in the south is nearly identical to that of the active fault traces depicted by [16]. However, it has a length of $18 \mathrm{~km}$, making it longer than the fault traces that have been previously depicted.

Small depressions, with widths of a few hundred meters, scatter to the southwest of the small scarps and are parallel to the scarps. The northeastern side of the small scarps are characterized by small narrow ridges. These topographical features are similar to those of both, the Tsujimiya fault at the Yoron island and the strike-slip fault, indicating that the Tsujimiya fault continued to the Yoron basin as the NNW-trending left-lateral strike-slip fault. 

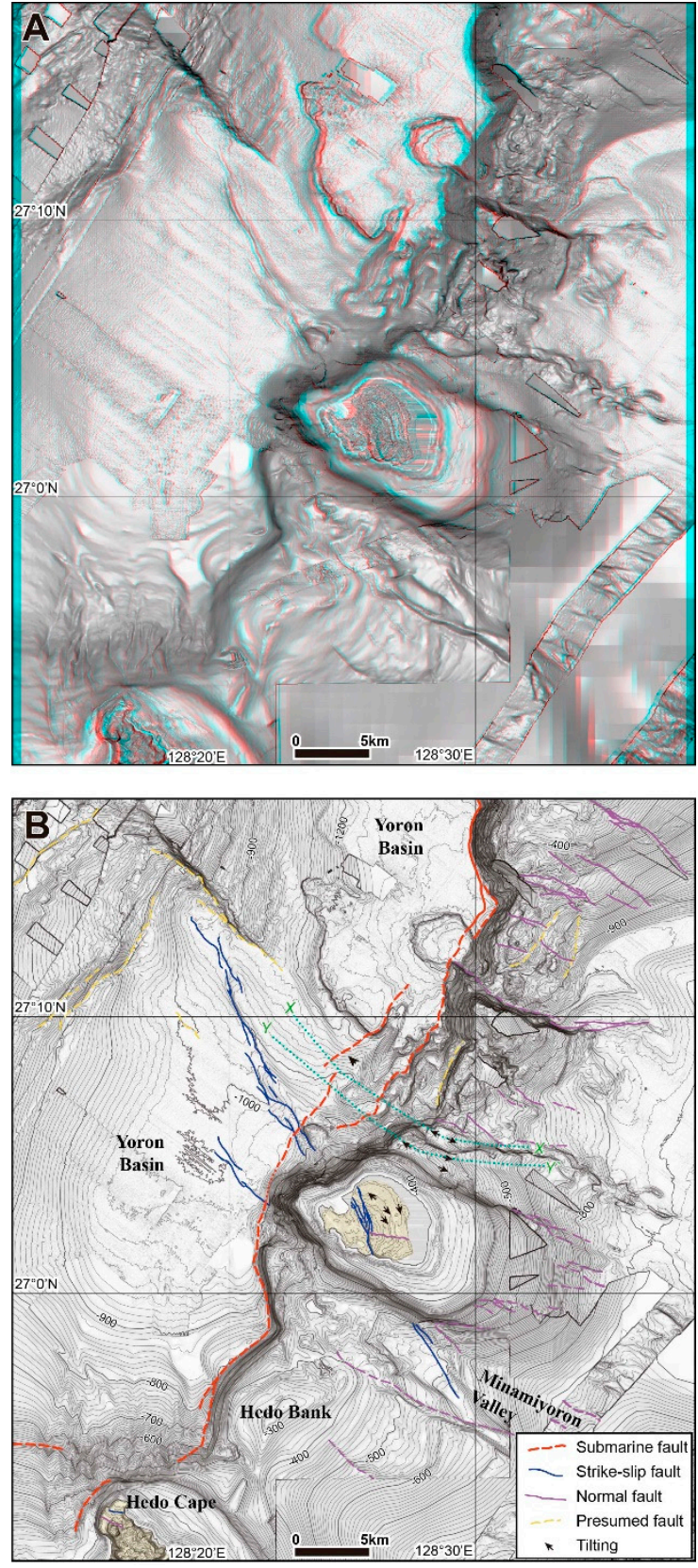

Figure 4. Topography around the Yoron island based on the 0.6-s-mesh DEM (approximately $19 \mathrm{~m}$ ) from the National Institute of Advanced Industrial Science and Technology (AIST), the 2-s-mesh (approximately $65 \mathrm{~m}$ ) from the Japan Agency for Marine-Earth Science and Technology (JAMSTEC), the 2-s-mesh (approximately $65 \mathrm{~m}$ ) DEM processed via digital bathymetric charts (M7020) from the Japan Hydrographic Association (JHA), the 500-m-mesh DEM (J-EGG500) from the Japan Coast Gard (JCG), and the on-land SRTM-3 data provided by the United States Geological Survey (USGS). (A) Topographical Anaglyph. (B) Topographical map overlain with the active fault distribution.

\subsection{Ground Deformation along the Island Arc}

\subsubsection{Marine Terrace Classification}

We identified the uplifted coral reef marine terraces via topographical anaglyph interpretation (Figure 3). We divided the northeastern region of the island, which was bounded by the Tsujimiya and Asato faults, into four terraces: the M1, M2, M3, and M4 surfaces in descending order. This classification is concordant with the lower four surfaces described in [23]. Although the M2 surface, the most 
prominent crest, was correlated to the marine terrace developed during MIS 5e and MIS $5 \mathrm{c}$ by [13,25], respectively, no geochronological data were observed to exist for these surfaces. The most reliable paleo-shoreline indicator among the marine terraces is the crest top on the uplifted coral reef. Thus, we mapped the crests of the M1, M2, M3, and M4 surfaces using the topographical anaglyph (Figure 3). We also mapped several ridges characterized by crest topography, outside the northeastern region of the island. The M4 surface crests near the coastline were mapped in a limited area due to the difficulties associated with identifying crests on the DSM data, which included the forest data near the coastline to capture the wind-blown sand from the beach.

\subsubsection{Marine terrace crest deformation.}

The crest of the M1 surface is left-laterally offset by approximately $150 \mathrm{~m}$, along the most eastern strand of the Tsujimiya fault. This is due to the ridge direction, which is oblique to the fault. The three narrow ridges between the fault scarps are almost identical to the M1 surface, indicating that there is a correlation to the M1 surface. However, we did not estimate the lateral offset along the M2 surface, due to the presence of two parallel ridges on the west side of the fault.

We measured the crest height using the DSM and aligned this data onto the NW trending axis, which is perpendicular to the general direction of the island shelf (Figure 5A). From this figure, we detected the anticlinal deformation along the crest of the M2 surface, which was the longest and most distinguished ridge, whereas [23] reported only southward tilting. It is possible that we have only observed anticlinal deformation along the southern flank of M1 and M3. The ratio of southward tilting along the M1, M2, and M3 crests are approximately $8 \%, 6 \%$, and $4 \%$, respectively.
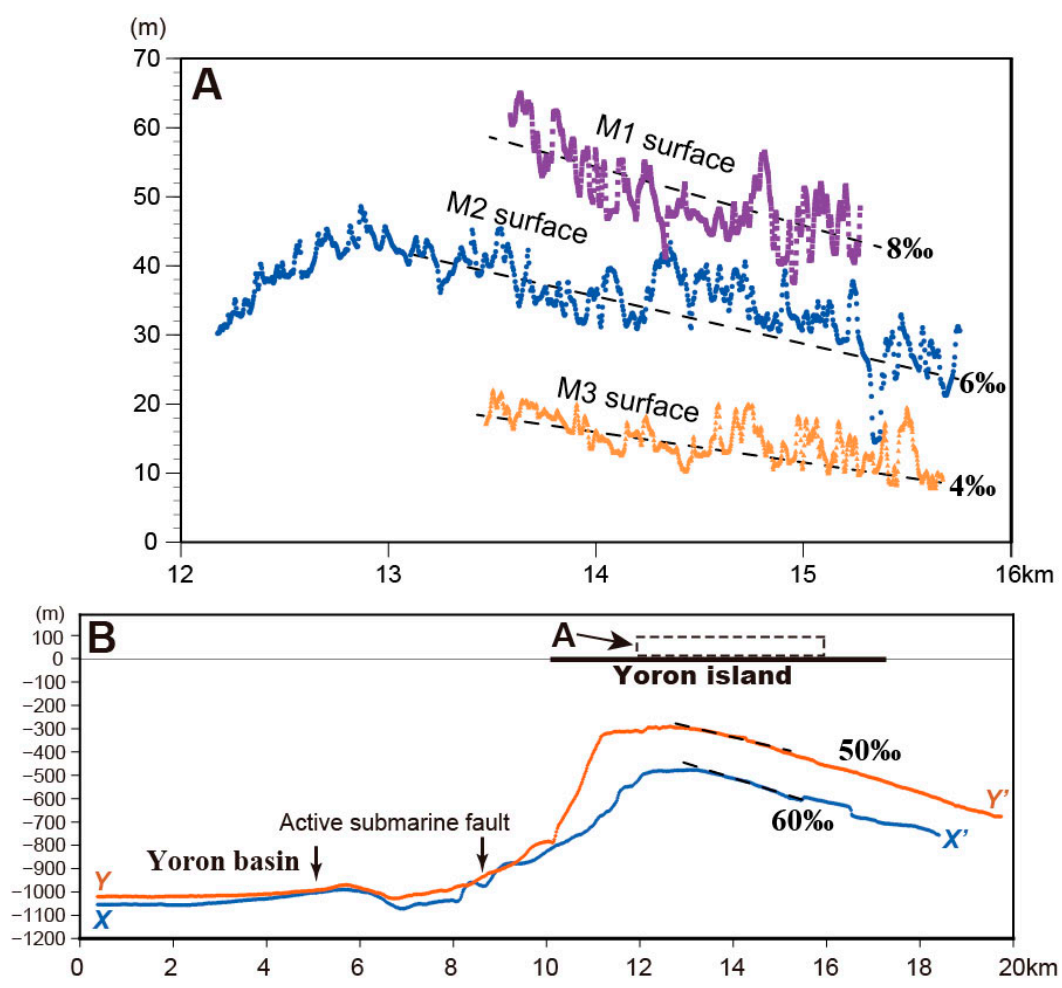

Figure 5. (A) Topographical profiles of the uplifted coral reef crests at the Yoron island, based on the DSM. (B) Topographical profiles across the Yoron basin and island shelf based on the DEM data from the source of Figure 4. The location of the profiles in Figures A and B are presented in Figures 3 and 4 , respectively. 


\subsubsection{Seafloor Topographical Features around the Yoron Island}

More than 500-m high steep slopes border the Yoron basin toward the east under which we have identified the submarine faults that are bordered by accumulated basin sediments and seismic basement [14]. In this area, the upslope surfaces of the island shelf exhibit a convex shape and are unsymmetrically inclined to the northwest and the southeast sides. The summits of these surfaces are parallel to the steep slope and are located within $5 \mathrm{~km}$ from the southeastern edge of the basin (Figure 4). A gentle convex slope to the southeast extends farther than that to the northwest. We observed this slope on topographical profiles across the basin and the island shelf (Figure 5B). This surface's southeastward tilting ratio is approximately $50-60 \%$, which is much larger as compared with that of the inland marine terraces.

\section{Discussion}

The two seafloor surfaces are located at approximate depths of 400 and $500 \mathrm{~m}$ to the north of the Yoron island (Figures 4 and 5), are due to the deformation of the flat slope and the difference of erosion. In this study, we consider deformation to be the cause, because the shape of the longitudinal profile is similar to that of the crests of the marine terrace (Figure 5A). The geological results observed toward the south of the Yoron island may be correlated with those of the north of the island as follows. Around the Hedo bank, to the south of the Yoron island, island shelf surfaces were formed to flatten the Hedo-oki group sediment of the Pleistocene and the Kunigami-oki group sediment of the Eocene based on the geological section via erosion [14]. These are the possible results of seafloor surface deformation after at least the Pleistocene, which may have been formed from the anticlinal deformation.

We identified anticlinal deformation on the Pleistocene marine terrace at Yoron island, and presented the possibility of the anticlinal deformation of the seafloor to the north of the island, using topographical anaglyphs obtained from the inland DSMs and seafloor DEMs. The deformation axis extends in a line and is parallel to both the island shelf's general trend, and the eastern edge of the Yoron basin. This axis is located within $5 \mathrm{~km}$ of the basin edge and is approximately $100 \mathrm{~km}$ away from the Nanseishoto trench. Results indicated that this deformation continued at least throughout the Pleistocene, and that this was closely related to the active submarine faults along the eastern edge of the Yoron basin. These active submarine faults are possibly reverse faults, due to the common topographic feature associated with the inland reverse faults and the absence of the antithetic faults in the Yoron basin. We have to further examine the geological structure of this area in the future.

For the marine terraces at both the Yoron island and basin, we identified several geomorphic features associated with active strike-slip faults, which were oblique to the island shelf using the topographical anaglyph. We observed small scarps on the island shelf perpendicular to the island shelf's direction, which were associated with the normal faults reported by the results of a seismic survey (e.g., [14]). This active fault and active anticlinal deformation distribution pattern along the outer arc ridges are similar to the areas near Aceh, Sumatra, where both oblique strike-slip faults and perpendicular normal faults cut the isolated narrow ridges along the trench [26]. The distribution and style of these active faults and deformations can be possibly explained, if the horizontal compressive stress axis is perpendicular to the island shelf.

\section{Conclusions}

In this study, to reinvestigate the tectonic geomorphology in and around the Yoron island of Ryukyu arc, we produced the extensive topographical anaglyphs that cover the inland and seafloor. Several small active faults have cut and deformed the marine terraces on this island. However, the extension and style of faulting are not well documented because the areas of the island and terraces have limited exposure, and there is a lack of detailed topographic data. To reveal the topography of inland, vintage aerial photographs are used to produce the 3-m mesh inland DSM; furthermore, for the topography of the seafloor, the 0.6 -s to 2-s-mesh DEM is processed using previous surveys. 
We examined the tectonic geomorphological features using extensive area maps of topographical anaglyph, and presented novel tectonic maps of the late Quaternary. The results revealed that the 4-km-long Tsujimiya fault scarps across Yoron island, are composed of only the south part of 18-km-long strike-slip faults. We also identified anticlinal deformation on the Pleistocene marine terrace at the Yoron island and the seafloor to the north of the island, suggesting that this deformation continued at least throughout the Pleistocene.

This study represents a possibly effective methodology to understand the island arc tectonics, particularly in the areas which are characterized by small isolated islands. To be useful for future studies, this method requires detailed data from the coastal area for storage and distribution.

Author Contributions: H.G. conceived, designed, and performed the study. H.G. wrote the paper. K.A. discussed, reviewed, and edited with H.G. T.S. contributed materials and analysis.

Funding: This work was partly supported by MEXT KAKENHI grant numbers 16K01221 and 16H01829.

Conflicts of Interest: The authors declare no conflict of interest.

\section{References}

1. Goto, H.; Sugito, N. Fault geomorphology interpreted using stereoscopic images produced from digital elevation models. E-J. GEO 2012, 7, 197-213, (In Japanese with English abstract). [CrossRef]

2. Goto, H. Extensive Area Map of Topographic anaglyphs covering inland and seafloor from detailed digital elevation model for identifying broad tectonic deformation. In Earthquakes, Tsunamis and Nuclear Risks: Prediction and Assessment Beyond the Fukushima Accident; Kamae, K., Ed.; Springer: Tokyo, Japan, 2016; pp. 65-74. ISBN 978-4-431-55820-0.

3. Goto, H.; Tsutsumi, H.; Toda, S.; Kumahara, Y. Geomorphic features of surface ruptures associated with the 2016 Kumamoto earthquake in and around the downtown of Kumamoto City, and implications on triggered slip along active faults. Earth Planets Space 2017, 69, 26. [CrossRef]

4. Goto, H. Late Quaternary slip rates and vectors on the Median Tectonic Line active fault zone in eastern Shikoku, southwest Japan. Quat. Int. 2018, 471, 267-277. [CrossRef]

5. Nakata, T.; Goto, H.; Watanabe, M.; Suzuki, Y.; Nishizawa, A.; Izumi, N.; Horiuchi, D.; Kido, Y. Active Faults along Japan Trench and Source Faults of Large Earthquakes. In Proceedings of the International Symposium on Engineering Lessons Learned from the 2011 Great East Japan Earthquake, Tokyo, Japan, 14-15 March 2012; pp. 254-262.

6. Izumi, N.; Nishizawa, A.; Horiuchi, D.; Kido, Y.; Nakata, T.; Goto, H.; Watanabe, M.; Suzuki, Y. 3D bathymetric image of the eastern margin of the Sea of Japan based on 3-second grid DEM. Rep. Hydrogr. Oceanogr. Res. 2014, 51, 127-139.

7. Matsumoto, T.; Shinjo, R.; Nakamura, M.; Kimura, M.; Ono, T. Submarine active normal faults completely crossing the southwest Ryukyu Arc. Tectonophysics 2009, 466, 289-299. [CrossRef]

8. Kan, H.; Urata, K.; Nagao, M.; Hori, N.; Fujita, K.; Yokoyama, Y.; Nakashima, Y.; Ohashi, T.; Goto, K.; Suzuki, A. Submerged karst landforms observed by multibeam bathymetric survey in Nagura Bay, Ishigaki Island, southwestern Japan. Geomorphology 2015, 229, 112-124. [CrossRef]

9. Katz, O.; Reuvena, E.; Aharonov, E. Submarine landslides and fault scarps along the eastern Mediterranean Israeli continental-slope. Mar. Geol. 2015, 369, 100-115. [CrossRef]

10. Randall Schumann, R.; Minora Daniel, S.A.; Lindsey, R.M.; John, T.G.; McGeehinc, P. Tectonic influences on the preservation of marine terraces: Old and new evidence from Santa Catalina Island, California. Geomorphology 2012, 179, 208-224. [CrossRef]

11. Arai, K.; Matsuda, H.; Sasaki, K.; Machiyama, H.; Yamaguchi, T.; Inoue, T.; Sato, T.; Takayanagi, H.; Iryu, Y. A newly discovered submerged reef on the Miyako-Sone platform, Ryukyu Island Arc, Northwestern Pacific. Mar. Geol. 2016, 373, 49-54. [CrossRef]

12. Sibuet, J.-C.; Deffontaines, B.; Hsu, S.K.; Thareau, N.; LeFormal, J.P.; Liu, C.S.; ACT Party. Okinawa Trough backarc basin: Early tectonic and magnetic evolution. J. Geophys. Res. 1998, 103, 30245-30267. [CrossRef]

13. Koba, M. Distribution and age of the marine terraces and their deposits in the reef-capped Ryukyu islands, Japan. Quat. Res. 1980, 18, 189-208. [CrossRef] 
14. Arai, K.; Sato, T.; Inoue, T.; Oda, H.; Sato, T.; Itaki, T. Marine Geology Map of the Vicinity of Northern Okinawa-Jima Island. Marine Geology Map Series; no. 85 (DVD); Geological Survey of Japan, AIST: Tokyo, Japan, 2015; (In Japanese with English abstract).

15. The Research Group for Active Faults. Active Fault in Japan; Sheet Maps and Inventories Revised Edition; University of Tokyo Press: Tokyo, Japan, 1991; (In Japanese with English abstract).

16. Odawara, K.; Iryu, Y. Pleistocene coral reef deposits (the Ryukyu Group) on Yoron-jima, Kagoshima prefecture, Japan. J. Geol. Soc. Jpn. 1999, 105, 273-288. [CrossRef]

17. Koukouvelas, I.; Zygouri, V.; Nikolakopoulos, K.; Verroios, S. Treatise on the tectonic geomorphology of active faults: The significance of using a universal digital elevation model. J. Struct. Geol. 2018, in press. [CrossRef]

18. Goto, H. Mapping of fault geomorphology using "Structure from Motion-Multi-View Stereo" photogrammetry with old/Hi-view aerial photography. Act. Fault Res. 2015, 73-83. [CrossRef]

19. Ishiguro, S.; Hiroya Yamano, H.; Oguma, H. Evaluation of DSMs generated from multi-temporal aerial photographs using emerging Structure from Motion-Multi-view stereo technology. Geomorphology 2016, 268, 64-71. [CrossRef]

20. Sato, T.; Oda, H. Bathmetry of GH12 cruise area (Okinoerabu Island-Okinawa Trough). In Arai ed. Marine geological and geophysical studies around Okinawa Islands-around Okinoerabu-jima Island-Preliminary reports on researches in the 2012 fiscal year. Geol. Surv. Jpn. Interim Rep. 2013, 61, 1-9. (In Japanese)

21. Japan Agency for Marine-Earth Science and Technology. Data and Sample Research System for Whole Cruise Information in JAMSTEC. 2016. Available online: http:/ / www.godac.jamstec.go.jp/darwin/ (accessed on 3 August 2018).

22. Goto, H. Submarine anaglyph images around Japan Islands based on bathymetric charts: Explanatory text and sheet maps. Hiroshima Univ. Stud. Grad. Sch. Lett. 2013, 72, 1-74, (In Japanese with English abstract).

23. Hirata, K. Ecological studies on the recent and raised coral reefs in Yoron island. Sci. Rep. Kagoshima Univ. 1956, 5, 97-118.

24. Arai, K.; Sato, T.; Murakami, F.; Yoshikawa, S.; Baba, H. Seismic surveys of northwestern Okinawa Island -preliminary results pf GH09 cruise. In Arai ed. Marine Geological and Geophysical Studies around Okinawa Island -northwestern off of Okinawa Island -Preliminary Reports on researches in the 2009 fiscal year. Geol. Surv. Jpn. Interim Rep. 2010, 51, 34-46. (In Japanese)

25. Ota, Y.; Hori, N. Late Quaternary Tectonic movement of the Ryukyu islands, Japan. Quat. Res. 1980, 18, 221-240, (In Japanese with English abstract). [CrossRef]

26. Permana, H.; Hirata, K.; Fujiwara, T.; Udrekh, E.Z.; Kawano, G.M.; Djajadihardja, Y.S. Fault pattern and active deformation of outer-arc ridge of northwest of Simeulue Island Aceh, Indonesia 2011. Bull. Mar. Geol. 2011, 26, 41-51.

(C) 2018 by the authors. Licensee MDPI, Basel, Switzerland. This article is an open access article distributed under the terms and conditions of the Creative Commons Attribution (CC BY) license (http:/ / creativecommons.org/licenses/by/4.0/). 